\title{
OS SENTIDOS DA PARIDADE DE GÊNERO NA BOLÍVIA E OS ELEMENTOS DA SUA CONSTANTE TRANSFORMAÇÃO
}

\author{
The Meanings of Gender Parity in Bolivia and the Elements of its Constant \\ Transformation
}

\begin{abstract}
Resumo
Investigo, ao longo deste estudo, a transformação dos sentidos atribuídos à paridade de gênero na Bolívia a partir da Assembleia Constituinte iniciada em 2006, que levou à aprovação, em 2009, da nova Constituição Política do Estado da Bolívia. Neste artigo, analiso os caminhos que levaram à paridade de gênero a partir do ponto de vista das transformações trilhadas pelos significados e justificativas a ela atribuídos pelas atrizes políticas chave desse processo. Partindo das entrevistas realizadas para este estudo, observo uma transformação contínua nos sentidos atribuídos à paridade, intimamente relacionada com as expectativas geradas pela entrada das mulheres no espaço da política formal. Divido as definições e justificativas para a paridade de gênero na Bolívia em três vias principais: (1) chachawarmi, (2) princípio democrático e (3) representação substantiva. Por fim, realizo considerações sobre a insuficiência da presença paritária e a ressignificação da paridade de gênero a partir de experiências de violência política contra mulheres.
\end{abstract}

Palavras-chave: paridade de gênero; chachawarmi; representação; democracia.

\begin{abstract}
Throughout this study, I investigate the transformation of the meanings attributed to gender parity in Bolivia since the Constituent Assembly, which began in 2006 and led to the approval in 2009 of Bolivia's new Political Constitution of the State. In this article, I analyze the paths that led to gender parity from the point of view of the transformations traced by the meanings and justifications attributed to it by the key political actors of this process. Based on the interviews conducted for this study, I reach a continuous transformation in the meanings attributed to parity, closely related to the expectations generated by the entry of women into the formal policy space. I divide the definitions and justifications for gender parity in Bolivia in three main ways: (1) chachawarmi, (2) democratic principle and (3) substantive representation. Finally, I reach debates about the insufficiency of parity presence and the re-signification of gender parity from experiences of political violence against women.
\end{abstract}

Keywords: gender parity; chachawarmi; representation, democracy.

\footnotetext{
1 Mestra em Ciência Política pela Universidade de Brasília, Doutoranda em Ciência Política do PPGCP da Universidade Federal de Minas Gerais. E-mail: anandawmarques@gmail.com. Cidade: Belo Horizonte.
} 
Os sentidos na paridade de gênero na Bolívia e os elementos da sua constante transformação | Ananda Winter

\section{Introdução}

Neste artigo, exploro os sentidos que são assumidos pela paridade de gênero na Bolívia, na medida em que a mesma é constitucionalizada em 2009 e são aprovadas no país, nos anos seguintes, leis de regime eleitoral que estabelecem como a paridade de gênero deve ser efetivada. A pergunta que guia esta pesquisa indaga quais os sentidos atribuídos à paridade de gênero na Bolivia pelas mulheres que participaram dos seus processos de institucionalização. Esta análise das formas pelas quais a paridade de gênero é explicada me leva à categorização de pelo menos três principais vias de definição: a paridade como princípio democrático; a paridade como representação substantiva; e a paridade como chachawarmi. No entanto, estes sentidos não são fixos e permanecem em constante comunicação, indicando que a paridade não é definida tão somente como algo em si, mas como um caminho, algo que pode levar a uma efetivação, seja da democracia, da representação substantiva ou do chachawarmi.

Para esta pesquisa, na qual realizo um estudo aprofundado do caso boliviano, foram coletados dados qualitativos a partir da realização de entrevistas semiestruturadas e de uma pesquisa documental que incluiu documentos produzidos por Organizações Não-Governamentais (ONGs) e movimentos sociais, bem como documentos oficiais que registram as alterações do sistema eleitoral boliviano desde 1997. As entrevistas foram realizadas com agentes que participaram de pelo menos um dos três momentos a seguir: da aprovação da lei de cotas em 1997; da Assembleia Constituinte iniciada em 2006; e da aprovação das leis do regime eleitoral de 2009 e 2010. Através das entrevistas, procurei identificar como diferentes atores definiram a paridade de gênero ao observarem às diferentes etapas do seu caminho; também, busquei entender as articulações e os fatores determinantes que condicionaram as aprovações alcançadas em cada um dos espaços $^{2}$.

Realizei quinze entrevistas ${ }^{3}$ com agentes que atuaram nos referidos processos através de diferentes esferas: partidos politicos, movimentos

\footnotetext{
2 Dedico-me em outro momento à construção da institucionalidade da paridade de gênero na Bolívia.

3 As entrevistas foram realizadas com atores importantes dos referidos processos a partir do mapeamento inicial realizado com Rosario Ricaldi, eleita para a Assembleia Constituinte pelo MAS IPSP
} 
Os sentidos na paridade de gênero na Bolívia e os elementos da sua constante transformação | Ananda Winter

sociais, ONGs ou Parlamento. As formas de atuação das agentes aqui entrevistadas variam entre: a representação formal através da eleição e via partidos políticos, na Assembleia Constituinte e na Assembleia Legislativa Plurinacional; a participação ativa e de lideranças em organizações sociais, indígenas ou não, que construíram o rascunho da Constituição; a assessoria técnica prestada à movimentos sociais indigenas e à ONGs feministas durante o processo constituinte ou como lideranças nestas próprias ONGs. Ademais, procurei incluir entrevistadas das diferentes clivagens que marcaram este período: urbanas, rurais, indígenas e não indígenas.

\section{Cenários da Bolívia pré-Constituinte}

Avanços para a ampliação da participação de mulheres na política formal vêm acontecendo na Bolivia há bastante tempo. Na esteira da ampla adesão de cotas de candidaturas femininas na América Latina e no mundo que marca a década de 19904, a Bolivia aprovou em 1997 a Lei de Reforma e Complementação ao Regime Eleitoral, a qual instituía que 30\% das listas de candidaturas de deputados/as plurinominais e senadores/as fossem ocupadas por mulheres; e que, para as candidaturas de deputados/as uninominais, um de cada três candidatos/as deveria ser mulher.

Em 2004, a Lei de Agrupações Cidadãs e Povos Indígenas ${ }^{5}$ foi aprovada e com ela a primeira normativa postulando $50 \%$ de candidaturas femininas. Paralelamente, permanecem os 30\% de cotas de candidaturas para mulheres nas listas de partidos políticos. Em entrevista, Erika Brockmann, senadora durante a aprovação da lei de cotas de 1997 e deputada quando aprovada a lei de agrupações cidadãs pelo MIR (Movimiento de Izquierda Revolucionaria), conta que neste momento ainda não eram feitas referências à paridade enquanto conceito.

Ainda antes da aprovação da lei de cotas na década de 1990, além de argumentos contrários alegando restrições à liberdade individual e à

(Movimiento al Socialismo - Instrumento Político por la Soberanía de los Pueblos) e hoje responsável de incidência política da ONG Coordinadora de la Mujer.

4 Ver mais em: KROOK, Mona Lena. Quotas for Women in Politics: Gender and Candidate Selection Wolrdwide. Oxford University Press, 2009.

5 Em 2004, quando é aprovada a lei que permite candidaturas por agrupações cidadãs e povos indígenas, a Bolivia está no auge da crise que leva ao colapso do sistema partidário; diante deste cenário, as agrupações cidadãs somadas aparecem como segunda maior força política, atrás apenas do IPSP-MAS. 
Os sentidos na paridade de gênero na Bolívia e os elementos da sua constante transformação | Ananda Winter

igualdade formal (ZABALA CANEDO, 1998), conforme entrevistadas ${ }^{6}$ que participaram dos bastidores da aprovação da lei de cotas apontaram, era comum ouvir opositores questionarem o percentual de $30 \%$, indagando porque não se reivindicava $50 \%$ de cotas. O que, em certa medida, abriu espaço para as reivindicações por 50\% em 2004. É interessante notar que, conforme ressaltado por Erika Brockmann em entrevista, a primeira aprovação do percentual paritário coincide com as primeiras narrativas que vinculam a participação política de mulheres ao conceito de chachawarmi, que parece ser fortalecido na medida em que ganham peso atores e visões indígenas no novo cenário boliviano, que culmina na Assembleia Constituinte.

Estes avanços foram conquistados, principalmente, através da organização de mulheres parlamentares integrantes da elite política boliviana, que construíram pontes interpartidárias através do Foro Politico de Mujeres, que reunia mulheres parlamentares e da sociedade civil. No entanto, convém salientar que estas mudanças aconteceram em uma década muito ligada ao neoliberalismo, o que criou uma posterior resistência entre mulheres indigenas campesinas originárias para a articulação com organizações de mulheres feministas e urbanas.

Dito isto, embora a análise detalhada do contexto que antecede a Assembleia Constituinte ultrapasse o escopo deste artigo, convém considerar elementos que marcam este período e que ajudam a entender alguns enquadramentos da paridade de gênero. Dado que seria impossivel retomar aqui todos os passos até a formação do MAS-IPSP, primeiro partido com base fundamentalmente indígena, bem como dos movimentos indígenas campesinos originários que protagonizaram a construção da Constituição de 2009, retomo apenas alguns elementos que considero chaves neste contexto.

Em primeiro lugar, vale destacar que entre os anos 1980 e 2000 ocorrem três processos organizativos que culminam nas três organizações mais atuantes do período constituinte: a CSUTCB (Confederación Sindical Única de los Trabajadores Campesinos de Bolivia), que combinava aspectos sindicais e camponeses, formada por cocaleiros, quechuas e aymaras; a CIDOB (Confederación de Indígenas del Oriente, Chaco y Amazonía de Bolivia), formada pelos indígenas nas terras baixas; e o CONAMAQ (Consejo Nacional

6 Erika Brockmann, deputada pelo MIR; Monica Novillo, ONG Coordinadora de la Mujer. 
Os sentidos na paridade de gênero na Bolívia e os elementos da sua constante transformação | Ananda Winter

de Ayllus y Markas del Qullasuyu), organização de inspiração comunitária dos ayllus (FRANCO PINTO, 2017). Além disso, outra organização que se torna fundamental do processo de transformação boliviano é a Confederación Nacional de Mujeres Campesinas, Indígenas y Originarias de Bolivia - Bartolina Sisa, que nasce como um braço da CSUTCB e mais tarde se iguala a ela em hierarquia.

No começo da década de 1990, aderem à CSUTCB os movimentos cocaleiros da região do Chapare que, conforme indica Deborah J. Yashar (2005, p. 185), estiveram envolvidos nas lutas pela legalização do consumo e da produção das folhas de coca, mobilizando, para isso, um discurso étnico em torno da coca e da sua importância para as comunidades indígenas. Conforme Clayton Cunha Filho (2011, p. 158), os cocaleiros reuniram questões do indigenismo com elementos do nacional-popular, já que estavam organizados em estruturas sindicalistas e tinham posturas anti-imperialistas e nacionalistas. Tal característica de união destes dois importantes elementos para o país, o indigenismo e o nacional-popular, é assumida posteriormente pelo MAS-IPSP, acionando simbologias do passado boliviano e, ao mesmo tempo, colocando a sim mesmos como alternativa possível ao neoliberalismo (CUNHA FILHO, 2011).

Fundado oficialmente por Evo Morales em 1999 e integrado pela Federación Única de Trabajadores Campesinos de Cochabamba e pelas federações cocaleiras, o MAS-IPSP cresce a partir das eleições nacionais de 2002 e é beneficiado pela crise dos partidos políticos tradicionais e a consequente insatisfação com o regime democrático, expressa principalmente através do que ficou conhecido como guerra da água (VAN COTT, 2008). O conflito eclode com a privatização, durante o governo de Hugo Banzer, dos serviços de água em Cochabamba e o salto de $200 \%$ das contas de água (PERREAULT, 2006). A partir daí, tem início uma série de mobilizações, reunindo diferentes setores da sociedade em marchas e bloqueios de estradas. Após o envio de tropas militares às ruas de Cochabamba, muitas prisões e uma morte, o governo é obrigado a voltar atrás e cancelar o contrato de concessão (PERREAULT, 2006).

De acordo com Cunha Filho (2011), surgem com estas reivindicações uma agenda política alternativa que permanece nos conflitos dos anos 
Os sentidos na paridade de gênero na Bolívia e os elementos da sua constante transformação | Ananda Winter

seguintes, aglutinando diferentes setores da sociedade em um projeto contra hegemônico. Assim, o governo sucessor de Sánchez de Lozada é marcado, logo no início, em 2003, por conflitos em torno de um novo imposto de renda que terminaram com trinta mortos no centro de La Paz. No mesmo ano ocorrem os conflitos conhecidos como Guerra do Gás, dessa vez impulsionados pela exportação do gás natural por portos chilenos, que garantiria altos lucros para as transnacionais envolvidas e um baixo retorno para a Bolivia (PERREAULT, 2006). Os conflitos tomaram as ruas de La Paz e se espalharam pelas cidades do país.Após dezenas de mortes de civis e militares, em outubro de 2003, Sánchez de Lozada renuncia e foge para os Estados Unidos.

É neste cenário que as eleições municipais de 2004 e a eleição presidencial convocada em 2005 dão vitória a Evo Morales e ao MAS, indicando como o partido soube conciliar a agenda dos novos atores politicos que transitavam entre o indigenismo e a esquerda trabalhista. Se em 1999 os três partidos mais expressivos do país ${ }^{7}$ somaram 49\% dos votos, em 2004 eles marcaram 15\%, ao passo que o MAS sozinho obteve $17 \%$ dos votos. Além disso, a multiplicação de atores em forma de partidos e agrupações cidadãs e de povos indigenas refletiu a falta de confiança nos partidos políticos e a crise da democracia representativa pela qual passava o país.

Perceber que a emergência dos novos atores indigenas e campesinos frente às medidas neoliberais da década de 1990 é simultânea às mobilizações de organizações de mulheres parlamentares e ONGs para a aprovação de leis de cotas de candidaturas para mulheres é fundamental para entender a construção da narrativa em torno da paridade. Isso porque a Assembleia Constituinte é marcada pela frustração com o período neoliberal e a recusa de modelos e temas entendidos como estrangeiros. Entraram no pacote do que se entendia como inovações neoliberais as ONGs, o gênero e tudo que o envolvia enquanto conceito. Lideranças indigenas entrevistadas, assim como assembleístas vinculadas ou não a ONGs, narraram a resistência ao que se entendia como uma imposição externa da agenda de mulheres ${ }^{8}$.

\footnotetext{
7 ADN - Acción Democrática Nacionalista; MNR - Movimiento Nacional Revolucionario e MIR - Movimiento de Izquierda Revolucionaria.

8 Rosario Ricaldi, foi assembleísta pelo MAS, hoje trabalha na ONG Coordinadora de la Mujer; Andrea Flores, presidente da ONG Organización de Mujeres Aymaras del Kollasuyo; Rosalia de Vilar, assembleísta pelo MAS; Monica Novillo, diretora executiva da Coordinadora de la Mujer; Segundina Flores, presidente da Confederación Nacional de Mujeres Campesinas, Indigenas y Originarias de Bolivia - Bartolina Sisa.
} 
Os sentidos na paridade de gênero na Bolívia e os elementos da sua constante transformação | Ananda Winter

De toda forma, a paridade de gênero foi incluída na nova Constituição. Em 2009, a Lei de Regime Eleitoral Transitório incluiu uma forma prática para a paridade em seu artigo 9, que determina que as listas de candidatos/as a senadores/as, deputados/as, assembleistas departamentais e conselheiros/as municipais sejam compostas de modo que exista um candidato titular homem e em seguida uma candidata titular mulher, uma candidata suplente mulher e um candidato suplente homem ou vice-versa. No caso das circunscrições uninominais, a alternância é expressa em titulares e suplentes em cada circunscrição.

Já no ano seguinte, a Lei 026 de Regime Eleitoral avançou em relação às candidaturas uninominais, postulando que seriam garantidas $50 \%$ de candidaturas como titulares em circunscrições uninominais. Assim, além de incluir as listas paritárias e alternadas tal como postuladas pela lei transitória de 2009, o artigo 11 também assegura que pelo menos 50\% do total candidaturas titulares em circunscrições uninominais deveriam ser de mulheres. Ademais, o artigo inclui um parágrafo que assegura que estes princípios de paridade e alternância também deveriam ser respeitados nas listas de candidaturas de nações e povos indigenas, originários e campesinos.

Em geral, para explicar o que definia a paridade de gênero neste período entre a Assembleia Constituinte e $\mathrm{s}$ leis de regime eleitoral, as respostas variaram entre "número" e chachawarmi. Claro que, em um estudo sobre a paridade de gênero e com perguntas relativas à sua definição, é normal que boa parte das respostas incorpore a questão numérica. Assim, para perguntas sobre como foi definida a paridade politica entre o período constituinte e a lei do regime eleitoral, era comum ouvir respostas tais quais "bom, como somos metade da população" ou ainda "paridade significa 50 $50 "$.

É importante notar que a restrição ao aspecto descritivo da representação paritária apareceu apenas em uma das sete entrevistas que fizeram referência ao número. No entanto, para agentes com atuações importantes neste período, debates referentes ao caráter substantivo da presença feminina na esfera representativa ou sobre as possibilidades de avanço de uma agenda específica não tinham tanta força como a questão descritiva e simbólica de finalmente as mulheres serem metade do total de 
Os sentidos na paridade de gênero na Bolívia e os elementos da sua constante transformação | Ananda Winter

representantes; a ausência destes debates não significa, no entanto, a ausência de expectativas relacionadas a esta questão.

Para esta análise, acredito que seja importante considerar que a pesquisa foi realizada doze anos depois do início do processo constituinte e oito anos depois da lei do regime eleitoral, o que pode ter distanciado alguns aspectos do significado da paridade durante aquele período ao mesmo tempo em que permitiu a percepção de elementos sobre as expectativas e frustrações com a presença paritária que não teriam sido formulados ou externalizados em outros momentos. Destaco, principalmente, às frustrações relativas à insuficiência da presença numérica. Em certo sentido, estas frustrações estão ligadas aos constantes relatos de violência política sofrida pelas mulheres e a estruturas partidárias antidemocráticas que impossibilitam a sua participação efetiva, para além da presença.

Inicio com as narrativas que aproximaram a participação política de mulheres à dualidade andina; em seguida, parto para as outras duas vias: aquela que relaciona a representação paritária a um requisito básico para a democracia e para a justiça, inevitável no cenário de inclusão democrática vivido pela Bolivia; e aquela ligada aos argumentos referentes à representação substantiva. Em seguida, procuro evidenciar de que forma a representação numérica paritária foi definida como insuficiente e como são perpetuadas formas de violência politica contra as mulheres.

\section{Chachawarmi: uma definição andina para a paridade de gênero?}

A noção andina de chachawarmi pode ser traduzida como complementaridade de gênero. Embora algumas vezes o conceito seja traduzido de forma literal, chacha para homem e warmi para mulher, tendo a concordar com María Lugones quando considera que este tipo de tradução reduz o caráter relacional que esta noção envolve. Além disso, as noções de chacha e de warmi parecem mais flexíveis do que a tradução para os termos ocidentais; alguns estudos indicam como os mesmos indivíduos, ou objetos, podem ser ao mesmo tempo chacha e warmi, a depender da relação que buscamos entender (LUGONES, 2010; BURMAN, 2011). 
Os sentidos na paridade de gênero na Bolívia e os elementos da sua constante transformação | Ananda Winter

Como apontou Pilar Uriona ${ }^{9}$ em entrevista, em um contexto em que conversava sobre descolonização, falar em paridade de gênero era algo que fazia com que boa parte das mulheres não se sentisse representada. Nesse sentido, o protagonismo que assume a noção andina de complementaridade está relacionado à percepção corrente do gênero como um elemento externo à realidade boliviana.

As mulheres tinham também a necessidade de manter um discurso emancipatório dentro das suas lógicas culturais. [...] Como Aymaras ou mulheres de outras organizações com forte identidade indígena, preferiam colocar o tema da dualidade, ou da complementaridade, ou o par andino tradicional do chachawarmi. E isso foi muito forte para ter um elemento significativo de debate, um entendimento entre o que poderia significar para o movimento de mulheres e os movimentos sociais de mulheres indígenas e populares e entrar em um conceito que apontava para essa lógica de paridade, mas em seus próprios termos e práticas. (Entrevista com Pilar Uriona, realizada em 28 jul. 2018, tradução da autora).

Para Andrea Flores ${ }^{10}$, pelo menos enquanto conceito, o gênero não fazia parte das vidas cotidianas das mulheres indigenas, causando estranhamento e resistência na medida em que foi associado com mais uma imposição colonial. Para mais, nas palavras de Andrea Flores, muitas mulheres indígenas participantes do processo constituinte não sabiam o que era o conceito de gênero.

O gênero como categoria não só era incompreendido como também rebatido com considerações sobre a complementaridade tradicional andina, indicando como a desigualdade de gênero não poderia ser um problema das comunidades originárias. Rosario Ricaldi, por exemplo, contou que as mulheres indígenas teriam mobilizado o chachawarmi, inicialmente, como algo que tornava leis de paridade gênero na política, ou ainda uma agenda politica de gênero, incompativeis com a realidade originária do país. Ademais, Mala Htun e Juan Pablo Ossa (2013) identificaram que, ao assumir o governo, o discurso oficial do partido de Evo Morales continuou focado na superação da opressão étnica, assumindo que a desigualdade de gênero seria automaticamente superada uma vez que o colonialismo fosse extinto do país.

\footnotetext{
9 Pilar Uriona foi consultora técnica da ONG Coordinadora de la Mujer no período em que foi debatida e aprovada a Lei Transitória do Regime Eleitoral de 2009. A ONG ganhou protagonismo na formulação de agendas politicas construídas desde as mulheres a partir da Assembleia Constituinte.

10 Aymara e Presidente da Organización de Mujeres Aymaras del Kollasuyo, OMAK, ONG filiada à Coordinadora de la Mujer.
} 
Os sentidos na paridade de gênero na Bolívia e os elementos da sua constante transformação | Ananda Winter

Tenho a impressão que tanto a questão do estranhamento do conceito de gênero por parte de algumas mulheres, quanto a identificação da desigualdade de gênero como um problema a ser resolvido com a descolonização, podem ser endereçados por uma abordagem que percebe a colonialidade do gênero (LUGONES, 2010) e o entroncamento patriarcal causado pela colonização europeia (PAREDES, 2010; SEGATO, 2012). Neste sentido, recorro às posições do pensamento feminista referentes ao gênero nas formas de organização social descritas por Rita Laura Segato (2012). Em contraposição à compreensão do feminismo eurocêntrico que situa a opressão sofrida pelas mulheres de forma universal e admite a possibilidade de que avanços da sociedade moderna sejam estendidos às comunidades colonizadas, estão posições segundo as quais o gênero era inexistente no mundo pré-colonial.

Situada nesta posição que nega a existência do gênero antes da colonização, Lugones (2010, p. 748) descreve o gênero como imposição colonial que fixa dicotomias incompativeis com as cosmologias precedentes. Segundo a autora, a imposição do gênero pelo colonialismo cria uma nova organização das relações de produção e novas formas de conhecimento. Além disso a dicotomia entre homem e mulher como norma social ocorre por meio de um longo e constante processo de subjetificação dos colonizados (LUGONES, 2010, p. 748).

Segato (2012) descreve uma terceira posição, na qual situa a si mesma como aquela que, baseada em documentos históricos e etnográficos, percebe a existência de uma estrutura patriarcal pré-colonial e a presença de algo como relações de gênero em comunidades indígenas e africanas. Este seria um patriarcado de baixa intensidade, diferente da sua versão trazida pelos colonizadores europeus; ademais, apesar das relações e posições de gênero preservarem sentidos hierárquicos, as mesmas seriam mais flexiveis do que no mundo moderno ocidental (SEGATO, 2012). Neste sentido, o encontro ocasionado pela colonização de dois tipos de patriarcado transforma a estrutura de gênero das comunidades colonizadas.

A autora também situa nesta posição a feminista boliviana, fundadora do coletivo Mujeres Creando, Julieta Paredes. É de Paredes, na verdade, que ela empresta a noção de entroncamento patriarcal. Tal como Segato, Paredes 
Os sentidos na paridade de gênero na Bolívia e os elementos da sua constante transformação | Ananda Winter

(2010) considera que é necessário reconhecer que as relações injustas entre homens e mulheres são mais do que uma herança colonial; ainda, para ela, descolonizar o gênero seria, também, recuperar a memória ancestral de lutas contra uma opressão anterior à dominação cultural (PAREDES, 2010).

Mesmo admitindo a existência pré-colonial de relações de gênero que atribuem valores desiguais às atividades ligadas à feminilidade e à masculinidade, há espaço para entender que o advento da colonização implicou em uma transformação radical destas relações e aumentou as distâncias entre domínios femininos e masculinos. No entanto, a transformação destas estruturas não implicou uma transformação semântica no mesmo sentido, de modo que as mesmas nomenclaturas que antes davam sentido a uma dualidade complementar, como pode ser o caso do chachawarmi, passaram a designar uma relação binária e suplementar (SEGATO, 2012). Isso não quer dizer que não haja uma hierarquia prévia neste vocabulário, intensificada com o contato com as hierarquias ocidentais. Paredes (2010), por exemplo, considera que há uma disparidade inevitável no chachawarmi; para ela, recorrer a este imaginário é uma tentativa de dissimular a presença de um elemento que naturaliza discriminações e que não reconhece a situação real das mulheres nas comunidades indígenas.

Foge das possibilidades deste trabalho investigar em que medida as estruturas de gênero pré-coloniais eram ou não hierárquicas nas comunidades originárias bolivianas; de toda forma, é interessante observar a presença de algo que, na prática, correspondia a essa hierarquia de gênero e que pode ter sido endurecido com o contato colonial. Em um estudo etnográfico, Andres Burman (2011) cita, por exemplo, o silêncio das mulheres em assembleias aymaras, justificado tanto pelos participantes entrevistados por ele quanto por outros pesquisadores como herança colonial, dado que os europeus exigiam interlocutores masculinos.

Retomando as formas de definição do chachawarmi, achados de Stéphanie Rousseau (2011) indicam a complexidade da sua definição, podendo significar tanto a igualdade de participação de homens e mulheres em todas as esferas sociais, quanto remeter à ideia de que havia justiça de gênero no passado pré-colonial, ou ainda, servir para identificação de comportamentos abusivos entre os homens. Rousseau (2011) chega ao 
Os sentidos na paridade de gênero na Bolívia e os elementos da sua constante transformação | Ananda Winter

documento elaborado pelas Bartolinas, que expõe as suas contribuições para a proposta de Constituição e que deixa claro que a complementaridade não diz respeito a duas esferas exclusivas associadas a cada um dos gêneros, mas sim à dualidade que deve estar igualmente presente em todos os espaços (ROUSSEAU, 2011). É justamente este o sentido que parece ganhar força durante o período que precede a Assembleia Constituinte.

Ao discorrer sobre as consequências da mobilização do chachawarmi para as mulheres indígenas, Burman (2011, p. 85) considera que o fundamental seria entender até que ponto essa é uma noção que permite a manutenção de mecanismos de subordinação ou abre possibilidades de reivindicação de direitos das mulheres indígenas. No que toca ao recorte temporal deste estudo, a partir das percepções das minhas interlocutoras indígenas e rurais, de um lado, e brancas, feministas e burocratas, de outro, acredito que os dois sentidos estiveram presentes.

Burman (2011) conclui o seu estudo afirmando que ao invés de abordarmos esta noção andina apenas como uma leitura da realidade, a mobilização do chachawarmi deveria ser compreendida também como uma estratégia para a transformação. De fato, entendo que apesar de em um primeiro momento referências ao chachawarmi terem sido feitas como obstáculo, foi justamente seu uso estratégico para a transformação que prevaleceu e permitiu a ampla adesão de mulheres indígenas, campesinas e originárias a uma agenda despatriarcalizadora que incluiu, entre os seus objetivos, a presença paritária de homens e mulheres nos espaços formais de representação.

Por um lado, Rosario Paz ${ }^{11}$ reflete sobre aspectos deste recurso como uma estratégia que diminuía a entrada das mulheres. Ela considera que enquanto povos e representantes vindos do oriente do país permaneceram mais abertos a dar espaço às mulheres, os povos quechuas e aymaras, que teriam formas próprias de organização, permaneceram mais fechados.

Como se organizam, eles dizem chachawarmi aqui, a mulher e o homem vão juntos. Mas nós havíamos descoberto que não era bem assim. Que os homens se sentam aqui e um pouco mais atrás estão as mulheres. Muito mais caladas. [...] São sempre os dois, mas normalmente a mulher vai organizar um pouco mais as coisas e os

11 Deputada na década de 1990 e participante do Movimento Mujeres Presentes en la Historia. 
Os sentidos na paridade de gênero na Bolívia e os elementos da sua constante transformação | Ananda Winter

senhores vão tomar as decisões. (Entrevista com Rosario Paz, realizada em 17 jul. 2018, tradução da autora).

De acordo com Rosario Paz, para homens e mulheres quechuas e aymaras, as mulheres do mundo ocidental não poderiam entender a forma de organização das suas comunidades nas quais mulheres, homens e crianças participavam em conjunto.

Mas, não é tão assim. A divisão do poder, a tomada de decisão, a violência contra a mulher, as violações contra as meninas, tudo é igualmente terrivel, como no nosso mundo. (Entrevista com Rosario Paz, realizada em 17 jul. 2018, tradução da autora).

Por outro lado, Ingrid Zabala, deputada no período de 2010 a 2015, no qual ocorreram os debates e a aprovação da Lei 026 de Regime Eleitoral, que transformou os princípios paritários incorporados na Constituição em medidas práticas, conta como a paridade de gênero foi definida:

Para nós a estratégia para explicar era de chachawarmi, que devem estar em par para dirigir a casa, a comunidade, um município, um departamento, um país. Ou seja, levar a ideia de que tudo devia estar em par. (Entrevista com Ingrid Zabala, realizada em 25 jul. 2018, tradução da autora).

Erika Brockmann, em referência ainda à aprovação do percentual paritário da lei de agrupações cidadãs de 2004, explica como, também neste momento, o chachawarmi foi usado como estratégia:

Como estratégia, diziamos "se o chachawarmi é um conceito de complementaridade e tudo isso, faremos que se cumpra". Portanto, o chachawarmi tem que ser coerente e estar de acordo com a aplicação de $50 \%$. Esse argumento, neste momento de discurso indígena, já era irrefutável, ainda que eles não o cumpram. (Entrevista com Erika Brockmann, realizada em 14 jul. 2018, tradução da autora).

A ex-deputada e ex-senadora explica que, para ela, a noção de chachawarmi não é cumprida porque é uma utopia, um paradigma usado tal qual a igualdade de direitos que consta em todas as constituições, mas que não é aplicada na prática.

A forma como o uso estratégico do chachawarmi em aproximações com a igualdade de direitos, mais especificamente com a igualdade de gênero, pode ser entendida, se seguirmos Boaventura de Sousa Santos (2010), como uma tradução intercultural, um dos elementos para uma epistemologia do Sul. De acordo com ele, a tradução intercultural permite que diferentes experiências de mundo se tornem reciprocamente inteligiveis, a partir de um trabalho de 
Os sentidos na paridade de gênero na Bolívia e os elementos da sua constante transformação | Ananda Winter

identificação e interpretação de culturas que aponte preocupações similares que as perpassam (SOUSA SANTOS, 2010, p. 44). Como ele explica, a tradução intercultural parte de uma noção de que nenhuma das formas de conhecimento em questão é completa, visto que cada uma deixa de lado diferentes aspectos, estas também possuem pontos de união. O trabalho de tradução intercultural evidenciaria, neste sentido, os limites desta articulação ao mesmo tempo em que apontaria para as possibilidades de transformação contra hegemônica (SOUSA SANTOS, 2010).

Parece haver de fato este movimento na medida em que reivindicações que objetivavam um país com maior equilíbrio nas relações entre homens e mulheres - na sua participação política e no exercício da sua autoridade levaram à construção de pontes e diálogos entre as próprias mulheres. Assim, os vocabulários se tornaram inteligiveis e passaram a transitar entre diferentes grupos; de forma que assim como mulheres urbanas e mestizas se referem ao chachawarmi, mulheres de comunidades indigenas e originárias falam sobre paridade e igualdade de gênero. Nesse sentido, entendo que ao mesmo tempo em que há um uso estratégico do chachawarmi por parte das mulheres urbanas e do movimento feminista, a fim de uma aproximação dos significados andinos, também há um uso estratégico das mulheres andinas inseridas em espaços de poder e visibilidade que recorrem a sua própria estrutura de significados para reivindicar igualdade de gênero.

Do total de quinze entrevistas que realizei, em oito constam claras referências ao chachawarmi como fator presente e significativo para a paridade de presença política. Faz sentido que Segundina Flores, aymara e líder das Bartolinas, a única indígena dentre estas oito, também tenha sido a única que o definiu como uma realidade sua. Utilizo realidade não como algo que ela identifica na prática, mas como um princípio vivido em seu cotidiano. Ela mesma aponta como alguns espaços ainda não estão de acordo com o chachawarmi, como, por exemplo, a presidência e a vice-presidência, ambas ocupadas por homens. Entendo que as demais entrevistadas faziam referência a este conceito explicando a sua utilização.

Apesar de algumas respostas incluírem sentidos do conceito, todas mencionaram o seu papel norteador para o sentido que foi sendo dado, progressivamente, à paridade de gênero. É dificil dizer de onde partiu a 
Os sentidos na paridade de gênero na Bolívia e os elementos da sua constante transformação | Ananda Winter

primeira referência ao chachawarmi para justificar a presença paritária na política formal; seguindo a cronologia dos períodos descritos nas entrevistas que realizei, é o contexto da aprovação da lei de participação cidadã e a inclusão do percentual de 50\% de candidaturas femininas para as agrupações cidadãs e indigenas, em 2004 que aparece como o primeiro momento em que o chachawarmi foi usado como recurso estratégico.

É claro que não possuo os meios para verificar se este foi de fato o momento de entrada desta via argumentativa, nem mesmo se ele foi, conforme relatado em entrevista, utilizado primeiro por feministas urbanas envolvidas na inclusão destes 50\% na referida lei. O que é possivel identificar é como ele assume um papel importante em uma narrativa própria de povos originários bolivianos, na medida em que estes acedem a novas posições de poder, e como a inserção de novas agentes políticas, mulheres indígenas, originárias e campesinas, permite novas pontes de diálogo e a construção de narrativas conjuntas.

\section{Paridade como requisito básico da democracia}

Como destaquei na seção anterior, apenas na entrevista que realizei com a lider das Bartolinas a paridade de gênero foi de fato definida como chachawarmi. As demais entrevistas que incluíram a complementaridade, explicaram-na mais como uma estratégia retórica de incorporar o vocabulário andino originário do que como uma percepção própria da realidade. Por outro lado, a definição da paridade como princípio democrático e de justiça foi compartilhada com maior propriedade. Em oito entrevistas, a paridade apareceu como um direito conquistado e um elemento básico da democracia. Algumas colocações foram incisivas em reforçar que o caráter democrático não está relacionado com a chegada de uma nova agenda, mas primeiramente com a chegada paritária ao espaço de poder.

O primeiro princípio que se cumpre é a democratização da representação, com isso é suficiente. Alguns me perguntam "que desempenho as mulheres têm?" E eu digo "bom, a melhor notícia é que alcançamos um nivel de representação que é democrática", ou seja, é a representação absoluta de homens e mulheres nos Estados. (Entrevista com Katia Uriona12, realizada em 12 jul. 2018, tradução da autora).

12 Diretora executiva da Coordinadora de la Mujer durante a Assembleia Constituinte e presidenta do Tribunal Superior Electoral entre 2015 e 2018. 
Os sentidos na paridade de gênero na Bolívia e os elementos da sua constante transformação | Ananda Winter

Aqui poderia estar presente o que Phillips (1995) considerou como um argumento de justiça quase intuitivo, o qual, ao mesmo tempo em que parece ser o mais convincente, reduziria elementos próprios da representação, na medida em que aproxima a representação justa da representação descritiva. No entanto, as falas que enfatizaram a paridade como primeiramente um requisito para a democracia vêm acompanhadas de considerações que me levam a ponderar se de fato há algo de reducionista nesta percepção.

Apenas uma das oito falas que classifiquei como mobilizando o argumento democrático não ponderou sobre a paridade numérica como insuficiente ou reforçou ideias no sentido de que a mesma possibilita uma melhor representação substantiva. Erika Brockmann respondeu que entende a paridade de gênero nos termos postulados por Rosa Cobo, como algo além de uma cota maior de candidaturas. Segundo ela, a paridade de gênero é:

Um princípio universal que reconhece a igualdade dos direitos
políticos das mulheres; não só como candidatas, mas como membros
efetivos e titulares de poder. A paridade é um elemento que não é
reversivel, como se supunha que as cotas seriam transitórias até o dia
em que fossem superadas as desigualdades entre homens e mulheres.
Não, a paridade é um horizonte, é um principio que está aí e que
ordena a busca permanente de um objetivo paritário entre homens e
mulheres como um principio igualitário da democracia. (Entrevista
com Erika Brockmann, realizada em 14 jul. 2018, tradução da
autora).

De acordo com Rosa Cobo (2002, p. 38) a paridade pode ser entendida, quando partimos de um paradigma de igualdade, como aquilo que concretiza a verdadeira universalidade, impossibilitada pelo patriarcado. Em parte, o que é colocado por Erika Brockmann remonta à discussão recuperada por Cobo (2002) referente às primeiras definições da paridade de gênero, mobilizadas na França, como um elemento que aperfeiçoa o princípio de universalidade. Segundo Cobo (2002), reivindicações por uma democracia paritária, ou por paridade, são parte de uma história de lutas feministas que se estendem desde as sufragistas. Ainda de acordo com ela, para o feminismo inscrito em uma tradição igualitária a democracia não pode ser legítima enquanto excluir metade da população (COBO, 2002, p. 38). Esta parece ser a premissa fundamental da qual partem as oito considerações que relacionam paridade e democracia. 
Os sentidos na paridade de gênero na Bolívia e os elementos da sua constante transformação | Ananda Winter

Neste sentido, independente da forma como complementam suas reflexões, seja constatando a insuficiência da presença numérica, seja explicando que a presença deve ser sucedida por outros elementos com a chegada de temas específicos à esfera representativa, estas entrevistadas asseguraram, em primeiro lugar, a paridade de gênero como "um direito democrático" ou como "uma condição básica da democracia". Katia Uriona ${ }^{13}$ e Monica Novillo ${ }^{14}$ marcaram de maneira mais enfática uma posição que afirma, em primeiro lugar, a "democratização da representação" através da paridade. De certa forma, em ambas as entrevistas a pergunta pelo que fazem as mulheres eleitas pareceu ser interpretada como uma desqualificação da presença.

Me incomoda um pouco que haja setores, inclusive feministas, que questionem a participação das mulheres como uma participação de enfeite. [...] Isso é uma falta de respeito às gestões que estão fazendo estas mulheres nestes espaços, porque estar neles não é fácil. São ambientes hostis, a própria cultura política dos partidos é hostil, e ainda criticam as mulheres. A partir dos movimentos feministas, nós brigamos para que os direitos de todas as mulheres, inclusive das que não são feministas, cheguem lá. Que tenham a possibilidade de, em certo momento, tomar decisões e participar nos espaços de decisão. Este é um princípio básico. Depois está o trabalho que temos que fazer nós, as feministas para que as mulheres que cheguem lá levem uma agenda e aí entra o tema da democracia paritária. (Entrevista com Monica Novillo, realizada em 17 jul. 2018, tradução da autora).

O trecho acima evidencia que, ao mesmo tempo em que há uma preocupação em marcar que a presença das mulheres não pode ser colocada em questão, independente do que façam enquanto representantes, reafirmando o aspecto democrático que a paridade cumpre por si só, a preocupação com a chegada de uma agenda politica alternativa por meio destas mulheres eleitas não deixa de estar presente. A entrevista com Katia Uriona também transparece esse posicionamento, que procura afirmar a importância de uma representação substantiva transformadora, ao mesmo tempo em que mantém que ela não é requisito para presença.

A representação que temos hoje é substantiva, é transformadora. Agora, que nós precisamos avançar muito mais porque ainda nos faltam muitos anos para que o patriarcado se vá é outra discussão. Mas você não pode devolver essa responsabilidade essencial às mulheres. "Ah, mas não é suficiente que as mulheres cheguem e se sentem lá e pronto", claro que não é suficiente, mas não é isso que as mulheres estão fazendo. As mulheres estão em cada espaço batalhando na disputa pelo poder, abrindo espaços [...]. Vivendo

\footnotetext{
13 Então presidente do Tribunal Supremo Electoral (TSE).
}

14 Atual secretária executiva da Coordinadora de la Mujer. 
Os sentidos na paridade de gênero na Bolívia e os elementos da sua constante transformação | Ananda Winter

violência para colocar uma agenda, para por outros temas em discussão, para democratizar o debate público. (Entrevista com Katia Uriona, realizada em 12 jul. 218 , tradução da autora) ${ }^{15}$.

Olhando para estas falas a partir de uma perspectiva mais ampla, elas parecem ser resultado de um momento em que, por um lado, a presença das mulheres é questionada pelas próprias mulheres de organizações sociais, feministas e acadêmicas; e, por outro, esta mesma presença parece ameaçada por denúncias de violência política, principalmente em nivel municipal. Monica Novillo fez referência como exemplo a uma entrevista com Sonia Montaño, conhecida feminista e socióloga boliviana, publicada poucos dias antes do nosso encontro, na qual ela considera que não é suficiente a presença de mulheres floreiros. Na mesma entrevista, Montaño indica que na Bolívia: "existe uma metade de mulheres que apenas levantam a mão no Parlamento e dizem amém ao executivo" 16.

Dessa forma, embora Monica Novillo e Katia Uriona tenham feito considerações sobre o conteúdo da representação e sobre a busca por meios de levar à esfera representativa uma agenda política alternativa, construída desde as mulheres, preocupações com possibilidades de retrocesso do que já foi alcançado podem ter levado às colocações que enfatizaram a aproximação entre presença paritária e democracia.

Onde eu vou eu escuto que as mulheres devem passar da sua chegada numérica à representação substantiva e eu digo que isso pode nos levar ao pior retrocesso. Porque enquanto éramos $14 \%$ ou $20 \%$ a posição geral era "elas que cheguem, não muda nada". E agora que chegamos e podemos dizer "temos condições de igualdade, sentem-se e vamos discutir" questionam essa chegada. Parece muito perverso, muito perigoso e, ainda, podem usar isso para o retrocesso. Porque, se alguém está perguntando "por que as mulheres chegam?" então, a resposta é "melhor que não cheguem". (Entrevista com Katia Uriona, realizada em 12 jul. 2018, tradução da autora).

\section{Insuficiências: representação e paridade substantiva}

Em certa medida, é possivel entender que o cenário de construção de redes entre organizações de mulheres diversas, inaugurado pela Assembleia Constituinte, permaneceu nos anos seguintes e foi essencial para

\footnotetext{
15 Não é meu objetivo nesta pesquisa me direcionar às perguntas e respostas referentes a que diferença fazem de fato as mulheres eleitas. Refiro-me aqui a este debate apenas na medida em que ideias em torno desta questão podem ser definidoras do que mobilizou e mobiliza as mulheres bolivianas em torno da paridade.

16 "No basta mujeres florero que levanten la mano para atrocidades". Sonia Montaño considera que es muy poco lo que hizo por las mujeres en el gobierno del MAS. Pagina Siete, La Paz, 10 jun. 2018.
} 
Os sentidos na paridade de gênero na Bolívia e os elementos da sua constante transformação | Ananda Winter

as articulações em torno das leis eleitorais. Embora as entrevistas com constituintes transpareçam impressões da integralidade da paridade como acompanhada de uma ampla agenda de mulheres, Monica Novillo e Pilar Uriona consideram que para a aprovação das leis do regime eleitoral em 2009 e 2010 a paridade de gênero foi definida como "basicamente número". Para elas, consolidada a paridade numérica, teriam aparecido de forma contínua mobilizações em torno de que tipo de participação politica era esperado das mulheres. Em relação a este ponto, Monica Novillo coloca:

Creio que toda a reflexão que fazemos agora sobre democracia paritária é posterior a termos conseguido mais participação das mulheres. Já conseguimos romper o teto de cristal da participação política, então, já podemos começar a discutir que tipo de participação politica queremos. (Entrevista com Monica Novillo, realizada em 17 jul. 2018, tradução da autora).

Assim, antes do processo eleitoral de 2014 foi produzida a Agenda Politica desde las Mujeres: una agenda para despatriarcalizar com cinco eixos principais, sendo eles: (1) democratização do poder e participação politica das mulheres; (2) desmontagem cultural, material e simbólica do patriarcado e nova institucionalidade; (3) garantias e condições para exercer o direito de viver livres de violência; (4) autonomia e autodeterminação dos corpos das mulheres; e (5) autonomia econômica das mulheres ${ }^{17}$. Para Pilar Uriona, o processo de construção de agenda, iniciado em 2014, permitiu a articulação das organizações de mulheres em torno dos eixos que consideravam mais importantes.

A construção de uma agenda das mulheres com a participação de diferentes instituições e organizações já acontecia desde a Assembleia Constituinte e se repetiu em 2011, após a aprovação da Lei 026. Talvez possa ser inferido aqui, considerando o que conta Pilar Uriona sobre o período entre 2014 e 2015, que cresceu o sentimento de que as mulheres eleitas deveriam levar consigo uma agenda construida de maneira coletiva. As falas que destacaram o aspecto democrático da presença foram complementadas com outros elementos, dentre os quais expressões de insatisfação com a paridade numérica. Insatisfações estas relacionadas tanto às expectativas de que as

17 COORDINADORA DE LA MUJER. Agenda Política desde las Mujeres: una agenda para despatriarcalizar. La Paz: Coordinadora de la Mujer, 2014. Disponivel em: www.coordinadoradelamujer.org.bo. Acesso em: 27 jan. 2019. 
Os sentidos na paridade de gênero na Bolívia e os elementos da sua constante transformação | Ananda Winter

mulheres eleitas levassem consigo conteúdos específicos quanto às barreiras impostas pelas estruturas patriarcais e antidemocráticas que impedem que a paridade de presença seja equivalente à paridade de poder.

Assim, de maneira geral, as frustrações foram no sentido de que (1) não há representação substantiva das mulheres ou, ainda, (2) de que a paridade numérica não significa paridade substantiva. Se para a primeira questão o problema estaria em como agem as representantes que não priorizam as agendas construídas em conjunto pelas organizações de mulheres, o que pode ser influenciado por fatores como fidelidade partidária, ou interesses relacionados às identidades étnicas e de classe, para a segunda, o problema estaria na não correspondência entre presença e poder. Apesar de serem questões diferentes, ambas guardam relações fundamentais ${ }^{18}$.

Tal como é definida por Pitkin (1967) em seu clássico estudo sobre o conceito de representação, a representação substantiva é aquela na qual quem representa age no interesse da pessoa representada. Embora o grau em que representantes agem no interesse de quem representam seja entendido de formas diversas, ele é geralmente definido pela medida em que são promulgadas pelos representantes leis que respondem às necessidades e demandas dos cidadãos (SCHWINDT-BAYER; MISHLER, 2005, p. 409). Dessa forma, a literatura dedicada a verificar a correspondência entre aperfeiçoamento descritivo da representação feminina com a representação substantiva das mulheres parte da hipótese de que mulheres eleitas agirão por outras mulheres, ou seja, com o seu aumento nos espaços deliberativos, aumenta a entrada de temas importantes para as mesmas.

Como apontam Sarah Childs e Mona Lena Krook (2009, p. 133) pesquisadores não costumam definir da mesma forma temas e assuntos que seriam relacionados às mulheres. Segundo elas, eles podem aparecer como temas que aumentam o bem-estar e a autonomia de mulheres, temas relacionados à esfera privada, preocupações com áreas em que existem desigualdades de gênero significativas ou questões que dizem respeito à sociedade em geral (CHILDS; KROOK, 2009, p. 133).

\footnotetext{
18 Aqui, levo em consideração tanto as entrevistas que realizei, como a minha experiência de campo no encontro nacional para a construção de uma agenda política a partir das mulheres para uma democracia paritária. O Encontro Nacional foi organizado pela Coordinadora de la Mujer e aconteceu durante os dias 03/07 e 04/07 de 2018, em La Paz, reunindo mulheres de diferentes organizações sociais e dos nove departamentos da Bolivia.
} 
Os sentidos na paridade de gênero na Bolívia e os elementos da sua constante transformação | Ananda Winter

Para entender as preocupações com a paridade substantiva, por outro lado, uso a definição dada pelas mulheres que participaram do Encontro Nacional de 2018, organizado pela Coordinadora de la Mujer. Durante o encontro, a garantia de uma paridade substantiva foi incluida entre os elementos da agenda em construção; a princípio, o adjetivo substantiva gerou desconforto e reclamações relacionadas ao fato de que nem todas as participantes entendiam o seu significado. Depois de alguns debates sobre a substituição ou não de paridade substantiva por paridade efetiva prevaleceu a primeira opção, definida como "aquela na qual há exercício pleno do poder, com direito de decisão".

De fato, os elementos da representação substantiva ou ligados aos desafios da paridade substantiva aparecem em diferentes considerações. Em algumas entrevistas apareceram colocações como "a presença já é uma questão democrática, mas mais democrático ainda é que levem uma agenda"; ou ainda reflexões sobre o aporte diferenciado:

Como já disse o presidente do Estado Plurinacional, o irmão Evo Morales, quando as mulheres estão é um olhar diferente. Ou seja, nós somos mais minuciosas, tratamos de cumprir $100 \%$, assumimos com tanta responsabilidade que cumprimos até o que não precisa. (Entrevista com Amalia Coaquira, realizada em 18 jul. 2018, tradução da autora).

Além de destacar o aporte diferenciado das mulheres ao espaço de tomada de decisão, Amalia Coaquira também expressou sua frustração com a atuação das eleitas ${ }^{19}$ :

Temos nossas deputadas, do nosso setor. [...] Mas elas têm a boca fechada. E o nosso questionamento é, precisamente, onde estão essas mulheres em quem votamos? O que estão fazendo por outras mulheres? Que políticas? Mas também vemos que elas estão nos espaços de decisões de poder, mas estão sozinhas nestes espaços, suas bases não estão lá. Estão sozinhas nos espaços de decisão e são manipuladas. (Entrevista com Amalia Coaquira, realizada em 18 jul. 2018).

Frustrações também foram expressas por Andrea Flores. Ao responder sobre a definição da paridade, a entrevistada incorporou uma referência ao seu elemento numérico e também a importância das posições alternadas para que a lei de paridade tenha resultados; além disso, através de exemplos de

\footnotetext{
19 Amalia Coaquira é secretária executiva da Confederación de Trabajadores por Cuenta Propia e se refere aqui às mulheres do seu setor.
} 
Os sentidos na paridade de gênero na Bolívia e os elementos da sua constante transformação | Ananda Winter

mulheres que foram eleitas, ela destacou a necessidade de que haja paridade de poder. Embora a presença paritária seja uma realidade, não é real a participação das eleitas:

Parece que o que vemos é que a mulher levanta a mão. Perguntam
"está de acordo?" e ela responde "sim". Mas não faz uma análise
política para dizer "eu como mulher observo isso" ou "gostaria que
mudássemos esse artigo". [...] Está ali presente, mas não te dão a
opção de fazer as propostas. Temos que decidir, sim ou sim, porque
eles já decidiram. Você é só mais uma pessoa ali, sem nenhuma
decisão. (Entrevista com Andrea Flores, realizada em 23 jul. 2018,
tradução da autora).

Embora estejam presentes questões referentes à falta de representação substantiva, e a própria construção de uma agenda política a partir das mulheres aponte para articulações em torno deste elemento, parece que o componente fundamental das atuais frustrações é a não correspondência entre paridade numérica e paridade substantiva, o que incide inclusive sobre o elemento anterior, a representação substantiva. Diferentes explicações são articuladas em torno desta falta de poder das mulheres eleitas. Por um lado, relatos de violência política são constantes desde o contexto anterior à Assembleia Constituinte até as referências ao momento atual; por outro, são exploradas as estruturas partidárias antidemocráticas e o próprio papel do partido majoritário do governo.

\section{Violência Política e Estruturas Antidemocráticas}

$\mathrm{Na}$ mesma entrevista em que Sonia Montaño considera que as mulheres eleitas apenas levantam a mão para aprovar o que é de interesse do Executivo, como colocou Monica Novillo, ela também afirma que a forte obediência e submissão do grupo parlamentar majoritário ao Executivo não permite espaços para a articulação conjunta de mulheres plurais. Para ela, como operavam como uma massa crítica, reunindo diferentes partidos, as mulheres eleitas através das cotas de 30\% no passado, antes da Assembleia Constituinte, conseguiram avançar mais do que as eleitas já com a lei de paridade.

Afirmações nesse mesmo sentido foram feitas por algumas entrevistadas. Marcela Revollo, assembleísta durante o processo constituinte 
Os sentidos na paridade de gênero na Bolívia e os elementos da sua constante transformação | Ananda Winter

e eleita deputada pelo Movimiento Sin Miedo (MSM) ${ }^{20}$ para a primeira Assembleia Plurinacional, em 2009, considera que na medida em que a realidade politica se normalizou, foi possivel perceber que apesar do percentual, o papel das mulheres não se transformou muito na cena política. Segundo ela:

A combinação de $50 \%$ de mulheres e maioria absoluta do partido do governo é uma péssima combinação para a emergência dos atores, porque essa combinação se traduz no silêncio dos novos atores para pagar esse aparente presente dado pelo partido dominante que é possibilitar a presença de novos atores. O que faz com que os $50 \%$ de mulheres tenham vindo acompanhados de um silenciamento. Porque a lógica de alianças foi rompida, privilegiando a submissão das mulheres aos chefes de partidos e, neste caso, ao partido do governo. (Entrevista com Marcela Revollo, realizada em 18 jul. 2018, tradução da autora).

Erika Brockmann também faz referência às dificuldades em manter alianças interpartidárias entre as mulheres; segundo ela, a união através do Foro Político de Mujeres, da década de 1990 até o período pré-constituinte, passou a ser muito difícil com a polarização gerada pelo MAS.

Essa polarização que persiste torna muito dificil a criação de uma nova coalizão de mulheres. A coalizão de mulheres vai paralela com a Coordinadora de la Mujer que é uma ONG que pode aglutinar os novos atores politicos. As mulheres dos setores populares, as mulheres cocaleras, as mulheres indigenas, são as novas agentes fundamentais do novo projeto político. Mas é muito difícil uma união visível, pública de mulheres plurais de diferentes partidos. (Entrevista com Erika Brockmann, realizada em 14 jul. 2018, tradução da autora).

Para Erika Brockmann, dentre os obstáculos que essa polarização traz à ação conjunta está a identificação das mulheres que estão articuladas independente de seus partidos político como traidoras. Segundo conta:

Existe o entendimento de que todas são guerreiras no MAS, são guerreiras porque têm que aprovar. Então levantam a mão para aprovar independente do que seja. Ou seja, não há ação reflexiva. E é a mesma coisa do outro lado, se uma mulher der as mãos às mulheres do MAS, logo escuta que está se vendendo ao MAS. (Entrevista com Erika Brockmann, realizada em 14 jul. 2018, tradução da autora).

Além de identificar um problema na maioria absoluta obtida pelo partido no governo nas duas últimas eleições nacionais, em 2009 e em 2014, a consideração de Marcela Revollo reflete um movimento frequente após o

\footnotetext{
20 Aqui, é interessante levar em consideração que o MSM, fundado pelo marido de Marcela Revollo, Juan del Granado, esteve ao lado do MAS até as eleições municipais de 2010, quando a aliança se rompeu em meio a declarações de Juan del Granado que acusavam o MAS de sectário, centralizador e antidemocrático.
} 
Os sentidos na paridade de gênero na Bolívia e os elementos da sua constante transformação | Ananda Winter

aumento de mulheres na esfera da politica formal, a compreensão de que a entrada feminina é apenas um passo para a "democratização da democracia" (CORNWALL; GOETZ, 2005). Para ela, a não transformação do papel das mulheres também guarda relações próximas com a ausência de medidas para a democratização interna dos partidos políticos.

Marcela Revollo dirige a sua crítica principalmente ao papel desempenhado pelo MAS-IPSP, que, segundo relata, apesar de ser o partido da maior parte das mulheres eleitas para o Senado e para a Câmara dos Deputados $^{21}$, devido as suas estruturas pouco democráticas elegeria um grande número de mulheres convenientes aos líderes partidários e sem uma trajetória política. Outras colocações também são feitas apontando que a democratização dos partidos é uma agenda pendente no país:

\begin{abstract}
Para as eleições de deputadas, assembleístas departamentais e concejalas foram cooptadas mulheres que não têm conhecimento, mulheres manejáveis, ou seja, submissas [...]. Mas mulheres com conhecimento, que vão contestar, que vão debater, não querem. É perigoso para os homens. (Entrevista com Amalia Coaquira, realizada em 18 jul. 2018, tradução da autora).
\end{abstract}

Dentre as funções dos partidos políticos, a designação de candidatos para postos políticos em todos os niveis do governo é, de acordo com Pippa Norris (2013), uma das funções tradicionais mais importantes. Norris (2013, p. 12) identifica três estágios que compõem este processo de indicação: 1) a certificação de que a candidatura é elegivel, baseada nas normas e nos estatutos partidários; 2) a nomeação, que combina as ofertas de candidaturas elegiveis com as demandas dos selecionadores dos partidos; 3) e a eleição, onde estão as demandas do eleitorado, da mídia e de apoiadores financeiros. São determinantes para este processo o grau de centralização e institucionalização dos partidos, que podem ser mais formais ou informais. Assim a escolha dos candidatos depende, para Norris (2013), do grau de centralização partidária, ou seja, em que medida as lideranças partidárias determinam as nomeações, cujo exemplo de prática em modelos descentralizados é a eleição primária para a seleção de candidaturas. Além disso, esta escolha também é influenciada pela amplitude da participação e escopo do processo de tomada de decisão (NORRIS, 2013, p. 14).

21 Nas eleições nacionais de 2014, eram do MAS 68,7\% das senadoras eleitas e 67,7\% das deputadas. 
Os sentidos na paridade de gênero na Bolívia e os elementos da sua constante transformação | Ananda Winter

Em relação às atuais estruturas partidárias na Bolívia, Diaz Carrasco (2017) identifica que eleições primárias não são adotadas por nenhum partido. No que diz respeito ao MAS-IPSP, ela aponta a existência de uma diversidade de critérios para a seleção de candidatos: para encontrar pessoas representativas da região, são buscadas as organizações sociais com maior número de militantes e capacidade de trabalho; depois, são localizados seus líderes; segue a esta pré-seleção uma negociação com o "chefe" do partido, Evo Morales. Ainda seguindo Diaz Carrasco (2017) o critério de seleção de candidatos da Unidad Demócrata (UN), de acordo com seu presidente, seria a sua visibilidade pública. Já representantes do Partido Demócrata Cristiano (PDC) disseram possuir critérios meritocráticos vinculados à vida profissional dos candidatos (DIAZ CARRASCO, 2017, p. 74).

A questão da democratização das organizações políticas estava em pleno debate na Bolívia no período em que realizei as entrevistas. Ela foi incluída no documento em construção da nova agenda política desde as mulheres e o Órgano Electoral Plurinacional, ainda presidido por Katia Uriona, havia recentemente apresentado um projeto de lei de organizações políticas, buscando estabelecer não só a democratização interna das organizações políticas, mas também incorporar a democracia paritária como seu princípio. O projeto foi aprovado, em setembro de 2018, como Lei 1096 de Organizações Políticas e regulamenta a adoção de eleições primárias internas para a escolha de candidatos, o que antes não era aplicado por nenhuma organização política (DIAZ CARRASCO, 2017).

Se anteriormente identifiquei a tendência em reforçar o avanço democrático da paridade numérica entre aquelas que ocupam posições institucionais importantes na elaboração de agenda e de normativas para a representação e paridade substantiva e que têm contato com perspectivas "de dentro", que expõem ameaças a estes avanços, aqui encontro uma tendência em relacionar as estruturas do MAS-IPSP e o que é entendido como atuação submissa das mulheres deste partido, com a ausência de paridade e representação substantivas. Considero importante, porém, um rápido contraponto que permita uma visão mais ampla.

Na entrevista já citada de Sonia Montaño, ela adentra a questão do referendo realizado no dia 21 de fevereiro de 2016 sobre a possibilidade de 
Os sentidos na paridade de gênero na Bolívia e os elementos da sua constante transformação | Ananda Winter

reeleição de Evo Morales, no qual ganhou a opção que dizia não à sua quarta candidatura. Para Montaño, o papel das mulheres deveria ser garantir a manutenção do Estado de Direito e respeitar o resultado do referendo. Aqui, ela entra na crítica à atuação das mulheres do MAS:

Que bom que houve inclusão social, que bom que as Bartolinas estão na parte mais visivel do poder. São mudanças simbólicas muito importantes, mas não basta que as mulheres estejam ali de enfeite para levantar a mão para atrocidades como o $21 \mathrm{~F}$. Se não há Estado de Direito, para que queremos estar no poder?22

Mobilizo este trecho da entrevista dado que expressa mais uma vez a compreensão de que, apesar de ser a maior porta de entrada de novos atores políticos, as mulheres que adentram a política pelo partido do governo, de acordo com parte das entrevistadas, permanecem subordinadas. Nas entrevistas que realizei essa crítica foi feita de maneira direta ao MAS por quatro mulheres, todas identificadas e com histórico de atuação no movimento feminista, todas urbanas e não indígenas. A crítica à posição subordinada ocupada pelas mulheres na politica, mas sem menções diretas ao MAS, inclui mais duas entrevistadas que, seja por uma questão de classe ou de etnia, integram os grupos de novos atores por outras entradas além do gênero. De maneira geral, foi frequente a impressão central da crítica de Montaño “do que adianta a presença se só levantam as mãos?”.

Como contraponto, trago três considerações. Em primeiro lugar, como é colocado por Diaz Carrasco (2017) em um estudo sobre o perfil de gênero nas organizações políticas, ainda existe uma divisão clara das mulheres que integram o MAS entre indigenas e ligadas ao mundo rural de um lado e as mulheres urbanas de outro. Trago este elemento para evitar generalizações que identificam as mulheres deste partido como Bartolinas e, consequentemente, apenas as Bartolinas com posturas submissas ao partido liderado por Evo Morales. Seria necessário um estudo mais detalhado sobre o comportamento e atuação legislativa destas mulheres para entender suas dinâmicas intrapartidárias.

Em segundo lugar, é importante levar em consideração algumas decisões importantes do partido, inclusive em uma dimensão simbólica para a entrada das mulheres no espaço politico formal. De fato, Evo Morales

22 "No basta mujeres florero que levanten la mano para atrocidades" Sonia Montaño considera que es muy poco lo que hizo por las mujeres en el gobierno del MAS. Pagina Siete, La Paz, 10 jun. 2018. 
Os sentidos na paridade de gênero na Bolívia e os elementos da sua constante transformação | Ananda Winter

estabeleceu uma relação próxima com as mulheres indígenas, principalmente com as Bartolinas e compôs o primeiro ministério paritário. Algumas das entrevistadas foram enfáticas em destacar o papel de Evo Morales e do seu partido para a aprovação da paridade de gênero.

Eu acredito que foi muito importante a liderança do Evo Morales, porque ele vinha das federações cocaleiras e nas federações de cocaleiros sempre eram mulheres e homens [...]. Ele estava acostumado a trabalhar par a par com as companheiras. Temos que reconhecer que se não fosse o seu apoio, sua decisão de dizer "bom, companheiros, companheiras têm que estar iguais, chachawarmi" não teria sido possivel. (Entrevista com Elizabeth Salguero, realizada em 5 jul. $2018^{23}$, tradução da autora).

O apoio de Evo Morales também foi considerado fator importante para os avanços em igualdade de gênero pela líder das Bartolinas, Segundina Flores. Além disso, já em referência à Lei de Regime Eleitoral de 2010, que aprovou as listas com alternância e paridade, Pilar Uriona, também mencionou em entrevista 24 o exemplo político de Evo Morales como fator importante na elaboração dos discursos que eventualmente convenceram as mulheres do MAS contrárias à paridade. Para Katia Uriona, diretora executiva da Coordinadora de la Mujer durante a Assembleia Constituinte e presidenta do Tribunal Superior Eleitoral entre 2015 e 201825, foi essencial para aprovação da lei de 2010 a decisão politica feita pelo MAS, que tinha uma bancada majoritária de dois terços da Câmara baixa:

Quando o MAS toma a decisão, a partir da atuação das próprias mulheres dentro do partido, com o apoio do movimento, se toma uma decisão política. Então, as resistências que existiam, chegam a um consenso político [...]. Nós estivemos em noites de vigilância e tudo, reforçando, mas eu acredito que o que houve foi uma decisão política. Se não fosse essa decisão, não importa o que argumentássemos [...] E essa decisão é gerada pelas próprias mulheres, não todas, mas aquelas que vinham de uma ação de movimento, que tinham uma trajetória de construir agenda. (Entrevista com Katia Uriona, realizada em 12 jul. 2018, tradução da autora).

Ainda no mesmo estudo, Diaz Carrasco (2017) observa que as mulheres estão presentes em todas as estruturas do partido, devido à incorporação da concepção andina do chachawarmi no seu interior. Resta

\footnotetext{
23 Elizabeth Salguero é, atualmente, técnica da ONU Mulheres. Foi deputada pelo MAS entre 2006 e 2010; Ministra de las Culturas, entre 2011 e 2012, embaixadora da Bolivia na Alemanha entre 2012 e 2015.

24 Entrevista realizada em 28 jul. 2018.

25 Katia Uriona apresentou sua carta de renúncia alguns meses depois da entrevista, em 22 de outubro de 2018, alegando a falta de autonomia do órgão na tomada de decisões.
} 
Os sentidos na paridade de gênero na Bolívia e os elementos da sua constante transformação | Ananda Winter

saber se a quantidade indica uma complementaridade real nesta organização (DIAZ CARRASCO, 2017, p. 75). Neste sentido, não é minha intenção desvalorizar o papel desempenhado pelo MAS, mas apontar as contradições que aparecem principalmente com o passar dos anos.

Como terceiro ponto destaco as participações de Segundina Flores e de Isabel Ramirez, ambas lideranças Bartolinas, durante o Encontro Nacional. Em meio a muitas falas que destacavam que tanto o encontro, quanto a agenda construída deveriam deixar de lado "as cores políticas", Segundina Flores foi a única a não seguir a cartilha e encerrou a sua fala com "viva o presidente Evo Morales". Já Isabel Ramirez falou, durante toda a sua participação, sobre a importância das mulheres fazerem com quem sejam ouvidas, e da necessidade de garantir a paridade efetiva, para que os homens não falem mais pelas mulheres e para que estas mulheres eleitas, concejalas ou deputadas, saibam que são capazes de tomar decisões. A entrevistada complementou afirmando que:

As coisas ruins não podem nos confundir porque, no fim, a direita está querendo voltar e a direita não pode voltar; porque nós já sofremos por 500 anos, irmãs e irmãos. Já não podemos sofrer. Temos que ver, se existem equivocos, precisam nos dizer de frente, irmãs. (Isabel Ramirez em 04/07/2018, durante pronunciamento durante o Encontro Nacional, tradução da autora).

Considerando estas falas, em conjunto com a entrevista de Segundina Flores, no momento em que esta questiona a composição da chapa para a presidência do MAS ainda ser composta por dois homens, Evo Morales e Álvaro Garcia Linera, entendo que o fato da manutenção do alinhamento à chapa do MAS-IPSP não significa, necessariamente, que elas apenas aceitaram a decisão dos líderes partidários. Ademais, este alinhamento pode indicar mais do que uma submissão que rompe com a defesa do Estado de Direito reivindicada por Sonia Montaño e apontar para uma decisão que observa os movimentos de reorganização da direita, o que desperta a memória recente do passado neoliberal.

Acredito que estas dinâmicas refletem parte das definições da paridade de gênero, talvez não no sentido de quais as justificativas e os argumentos que ela mobiliza, mas sim sobre em que aspectos ela gera frustração, o que pode dizer algo sobre o que se espera dela e para que cenário ela deveria caminhar. 
Os sentidos na paridade de gênero na Bolívia e os elementos da sua constante transformação | Ananda Winter

Desta forma, chego ao último ponto que gostaria de considerar, para o qual parto da afirmação de Rosario Paz:

Cada dia há um assédio político novo nos espaços municipais. Se você não tem condições medianas para uma vida livre de violência, é muito difícil o exercício do poder político. (Entrevista com Rosario Paz, realizada em 17 jul. 2018, tradução da autora).

Embora esta pesquisa não tenha sido realizada com foco nas formas de violência política presentes na Bolivia, este foi o elemento mais frequente durante as entrevistas. Dez entrevistadas abordaram este tema, em respostas a diferentes questões sobre as articulações entre mulheres, o significado da paridade ou sobre os conflitos no período constituinte e da aprovação das leis estruturais em 2010. Na verdade, a violência política apareceu como elemento presente e capaz de unir as mulheres desde os relatos sobre as atuações antes do início dos preparativos para a Assembleia Constituinte. Vale pontuar que algumas entrevistas enfatizaram que nem todas as mulheres estiveram favoráveis desde o início à aprovação da inclusão do direito à vida livre de violência na Constituição de 2009; também não foi sempre unânime a posição feminina em relação à lei contra a violência e o assédio político de 2012 .

Em um livro sobre a história da atual lei contra a violência política, Erika Brockmann (2017) escreveu que as primeiras denúncias de violência politica contra as mulheres foram feitas no ano 2000 por concejalas durante uma audiência pública solicitada pela Asociación de Concejalas de Bolivia (ACOBOL). A ACOBOL, fundada em 1999, realizou, a partir do ano 2000, um mapeamento das denúncias de assédio e violência politica contra concejalas e alcadesas. No mesmo livro, Brockmann (2017) traz os dados de violência coletados pela ACOBOL entre 2010 e 2014, período em que já estavam vigentes a paridade e a alternância; segundo indica, foram 300 casos; destes, 200 obrigaram mulheres a renunciar e dois trataram-se de feminicídios. Estes dois feminicídios foram lembrados em entrevistas e durante o Encontro Nacional.

Segundo Daniela Cerva Cerna (2014, p. 130), quando mulheres adentram a esfera política acessam um espaço de instituições e organizações fundadas na presença exclusiva de homens; assim, na medida em que elas põem em xeque o que correspondia à dominação tradicional destes, sua participação política é encarada como uma ameaça. Ainda de acordo com ela, 
Os sentidos na paridade de gênero na Bolívia e os elementos da sua constante transformação | Ananda Winter

parecem ser inerentes a mais mulheres na política situações de discriminação e violência de gênero; tais fenômenos ocorrem não só nas relações interpessoais, como nas próprias dinâmicas coletivas incorporadas nas lógicas de funcionamento partidário sustentadas em estereótipos que reproduzem discriminações de gênero (CERVA CERNA, 2014, p. 122). Mona Lena Krook e Juliana Restrepo Sanín (2016) consideram que ao mesmo tempo em que países latino-americanos apresentam amplas evidências de formas de violência política contra mulheres, também possuem uma variedade de possiveis soluções.

Conforme colocam Krook e Sanín (2016), é justamente a ACOBOL que elabora a primeira formulação de violência y acoso político hacia las mujeres enquanto conceito. Embora as iniciativas em torno de uma lei contra a violência política datasse dos primeiros anos da ACOBOL, foi em 2012 que ela foi aprovada. A Lei n ${ }^{\circ} 243$ - Lei Contra o Assédio e a Violência Política Contra as Mulheres, também constantemente mobilizada em entrevistas, tipifica dezessete tipos de violência política e define o assédio político e a violência política.

Seguindo o estudo de Brockmann (2017), desde o ano 2000 as denúncias de violência política incluem pressões para que as mulheres renunciem aos cargos para os quais foram eleitas, para que assumam seus suplentes homens. Conforme relatado em entrevistas, estas práticas continuam frequentes. Rosario Ricaldi 26 contou que foram adotados mecanismos para evitar que a pressão pela renúncia das titulares continue na Assembleia Plurinacional. Segundo ela, o meio encontrado é a obrigatoriedade de que durante uma semana de cada mês os suplentes substituam os titulares ${ }^{27}$; as práticas de assédio e violência para a renúncia continuam, no entanto, nos municípios e nos Estados. Katia Uriona descreveu estas práticas ao listar os retrocessos que ameaçam a participação política das mulheres. Segundo ela, estariam crescendo formas de "rotação de cargos", substituindo as mulheres titulares depois da metade (dois anos e meio) dos seus mandatos, pelos seus suplentes, sempre homens, como coloca a lei de paridade e alternância.

26 Constituinte pelo MAS e responsável de incidência politica da Coordinadora de la Mujer.

27 Embora não seja possivel verificar as razões da adoção desta medida, ela consta no Reglamento General de la Cámara de Diputados. 
Os sentidos na paridade de gênero na Bolívia e os elementos da sua constante transformação | Ananda Winter

\section{Considerações Finais}

No início deste artigo, propus a investigação sobre os sentidos contínuos da paridade de gênero na Bolívia, separando em três caminhos principais. O primeiro relacionado ao chachawarmi, o segundo ao aprofundamento democrático e o terceiro à representação substantiva. Até certo ponto, o chachawarmi parece guardar paradoxos parecidos com aqueles colocados por Rosa Cobo (2002) quando divide a paridade de gênero em argumentos de igualdade e diferença. Nesse sentido, quando olhamos para as formas em que o mesmo é definido, podemos ir da igualdade de participação em todos os espaços, orientada para ampliar a igualdade, liberdade e autonomia das mulheres, à afirmação de diferenças fundamentais e à manutenção de hierarquias através da afirmação da natureza dual da humanidade.

De toda forma, entendo que, de maneira geral, a preocupação de boa parte das agentes que mobilizaram este conceito não era nem seus conteúdos, nem suas contradições latentes, mas o seu potencial estratégico, que segundo elas mesmas indicam foi fundamental. Nesse sentido, levando em consideração as entrevistadas que abordaram especificamente à aprovação das leis do regime eleitoral, prevaleceram discursivamente justificativas como "basicamente número" ou chachawarmi, algo como um chachawarmi descritivo, pouco preocupado em definir de fato o seu sentido; de modo que a restrição ao aspecto descritivo, pelo menos neste momento específico, parece ter tido importância.

Apesar disso, as respostas sobre como é definida a paridade de gênero foram além deste momento, trazendo elementos fundamentais para uma compreensão atualizada dos seus sentidos na Bolívia. Entendo que o fato das afirmações do aspecto democrático serem acompanhadas por respostas sobre a definição da paridade de gênero que incluiam elementos sobre a representação substantiva e a falta de paridade de poder revela que também é atribuído um sentido de caminho, não só de ponto de chegada, à paridade de gênero.

Assim, tenho a impressão que embora tenha sido definida em momentos específicos de forma restrita ao aspecto numérico e à representação 
Os sentidos na paridade de gênero na Bolívia e os elementos da sua constante transformação | Ananda Winter

descritiva, estruturas patriarcais e de violência encontradas pelas mulheres que adentram o espaço político fazem com que cada vez mais a paridade tenha a democracia paritária e a despatriarcalização como horizonte. Entendo que o movimento de percepção de desigualdades de poder que segue à chegada aos espaços onde o mesmo é exercido permite a transformação e a ampliação dos sentidos da paridade de gênero e pode fazer o mesmo às formas com que as mulheres se apropriam e definem o chachawarmi.

\section{Referências}

ASAMBLEA LEGISLATIVA PLURINACIONAL. Lei $\mathbf{n}^{\circ} \mathbf{0 2 6}$, de 30 de junho de 2010. Ley del Régimen Electoral. La Paz, 2010. Disponivel em:http:/ / pdba.georgetown.edu/Electoral- /Bolivia/Ley26-2010.pdf. Acesso em: 7 fev. 2019.

BROCKMANN, Erika. El Acoso y Violencia Politica en Bolivia: Lecciones Aprendidas. Ciudad de México: Instituto de Investigaciones Jurídicas, 2017.

BURMAN, Anders. Chachawarmi: Silence and Rival Voices on Decolonization and Gender Politics in Andean Bolivia. Journal of Latin American Studies, v. 43, pp. 65-91, 2011.

CÁRDENAS, Felix et al. Despatriarcalización y Chachawarmi: avances y articulaciones posibles. La Paz: Ministerio de Culturas y Turismo; Vice ministerio de Descolonización, 2013.

CERVA CERNA, Daniela. Participación Política y Violência de Género en México. Revista Mexicana de Ciencias Politicas y Sociales, n. 22, pp. 117 $-140,2014$.

CHILDS, Sarah. The complicated relation between sex, gender and the substantive representation of women. European Journal of Women's Studies, v. 13(1): 7-21, 2006.

CHILDS, Sarah; KROOK, Mona Lena. Analysing Women's Substantive Representation: From critical mass to critical actors. Government and Opposition, Vol. 44, No. 2, pp. 125-145, 2009.

COBO, Rosa. Democracia Paritaria y Sujeto Político Feminista. Análes de la Cátedra Franciso Suárez, v. 36, pp. 29 - 44, 2002.

REPÚBliCA DE BOLIVIA. Constitución Politica del Estado Plurinacional de Bolivia (2009). Constitución Politica del Estado. Asamblea Constituyente; Honorable Congreso Nacional. La Pazl, 2009. 160 p. Disponivel em: <http:/ /www.ftierra.org/index.php/generales / 14-constitucion-politica-delestado>. Acesso em: $11 \mathrm{dez} .2018$. 
Os sentidos na paridade de gênero na Bolívia e os elementos da sua constante transformação | Ananda Winter

CORNWALL, Andrea. GOETZ, Anne Marie. Democratizing Democracy: Feminist Perspectives. Democratization, v. 12, n. 4, pp. 783-800, 2005.

CUNHA FILHO, Clayton Mendonça. Evo Morales e a Construção do Novo Bloco Histórico: entre o nacional-popular e o indigenismo. Oikos, v. 10, n. 2, Rio de Janeiro, 2011.

DIAZ CARRASCO, Marianela Agar. De Empleada a Ministra: despatriarcalización en Bolivia. Íconos Revista de Ciencias Sociales, v. 45, pp. 75-89, 2013.

DIAZ CARRASCO, Marianela Agar. Perfil de Género y de Paridad en las Organizaciones Políticas con Representación en la Asamblea Plurinacional de Bolivia. La Paz: Órgano Electoral Plurinacional, 2017.

ESTADO PLURINACIONAL DE BOLIVIA. Ley no 4021, de 14 de abr. de 2009. Ley de Régimen Electoral Transitorio. Ministerio de Autonomía. Estado Plurinacional de Bolivia, p. 1-43, abr. 2009. Disponível em: $<$ http://www.bivica.org/upload/ley-regimen-electoral-transitorio.pdf>. Acesso em: 20 jan. 2019.

ESTADO PLURINACIONAL DE BOLIVIA. Ley no 243, de 28 de mai. de 2012. Ley Contra el Acoso y Violencia Política Hacia las Mujeres. Asamblea Legislativa Plurinacional. Estado Plurinacional de Bolivia, mai. 2012.

FRANCO PINTO, Daniela. Insurgencias Femeninas Hacia el Epicentro del Poder (siglos XX-XXI). La Paz; Vicepresidencia del EstadoPlurinacional; Entidad de las Naciones Unidas para la Igualdad de Género y el Empoderamiento de las Mujeres, 2017.

HTUN, Mala; OSSA, Juan Pablo. Political Inclusion of Marginalized Groups: indigenous reservations and gender parity in Bolivia. Politics, Groups and Identities, v. 1, n. 1, pp. 4-24, 2013.

KROOK, Mona Lena. Quotas for Women in Politics: Gender and Candidate Selection Reform World Wide. Oxford University Press, 2009.

KROOK, Mona Lena. Empowerment versus backlash: gender quotas and critical mass theory. Politics, Groups and Identities, v. 3, n. 1, p. 184-188, 2015.

KROOK, Mona Lena; SANÍN, Juliana Restrepo. Gender Political Violence in Latin America, Concepts, Debates and Solutions. Política y Gobierno, v. 23, p. $125-157,2016$.

LUGONES, Maria. Heterosexualism and the Colonial/ Modern Gender System. Hypatia, v. 22, n. 1, 2007.

LUGONES, María. Toward a Decolonial Feminism. Hypatia, v. 25, n. 4, 2010.

NORRIS, Pippa. Women's Representation. Electoral Engineering: Voting Rules and Political Behavior. Cambridge: Cambridge University Press, 2004. 
Os sentidos na paridade de gênero na Bolívia e os elementos da sua constante transformação | Ananda Winter

NORRIS, Pippa. Recrutamento Político. Revista de Sociologia Politica, v. 21, n. 46, pp. $11-32,2013$.

NOVIllo, Monica. Paso a Paso. Así lo Hicimos.: Avances y Desafios en la Participación Política de las Mujeres. 1. ed. La Paz: Coordinadora de La Mujer - IDEA Institute For Democracy And Electoral Assistance, 2011. 114 p. v. 1

PAREDES, Julieta. Hilando Fino desde el Feminismo Comunitario. La Paz: Cooperativa el Rebozo, 2010.

PERREAULT, Thomas. From the Guerra del Agua to the Guerra del Gas: Resource Governance, Neoliberalism and Popular Protest in Bolivia. Editorial Board of Antipode, Oxford, 2006.

PHILLIPS, Anne. The Politics of Presence. Clarendon Press, Oxford, 1995.

PITKIN, Hanna. The Concept of Representation. University of California Press, Berkley, 1972.

ROUSSEAU, Stéphanie. Indigenous and Feminist Movements at the Constituent Assembly in Bolivia: locating the representation of indigenous women. Latin American Research Review, v. 46, No. 2. 2011.

SÁNCHEZ, Maria del Carmen; URIONA GAMARRA, Katia. De Tejidos y Entramados desde la Diversidad: sistematización de experiencias colectivas de las mujeres en el Proceso Constituyente, Post Constituyente y Autonómico. Coordinadora de la Mujer: La Paz, 2014.

SCHWINDT-BAYER, Leslie A.; MISHLER, William. An Integrated Model of Women's Representation. The Journal of Politics, v. 67, n. 2, pp. 407-428, 2005.

SEGATO, Rita Laura. Gênero e colonialidade: em busca de chaves de leitura e de um vocabulário estratégico descolonial. E-cadernos ces, [S. l.], n. 18, p. 18, 1 dez. 2012.

SOUSA SANTOS, Boaventura de. Refundación del Estado en América Latina: Perspectivas desde una epistemologia del Sur. Instituto Internacional de Derecho y Sociedad, Programa Democracia y Transformación Global: Lima, 2010.

URIONA GAMARRA, Katia. Desafios de la despatriarcalización en el proceso político boliviavo. T'inkazos, n. 28, pp. 33-49, 2010.

VAN COTT, Donna Lee. Radical Democracy in the Andes. Cambridge: Cambridge University Press, 2008.

VEGA UGALDE, Silvia. El orden de género en el sumak kawsay y el suma qamaña: un vistazo a los debates actuales en Bolivia y Ecuador. Íconos Revista de Ciencias Sociales, n. 48, pp. 73-91, 2014. 
Os sentidos na paridade de gênero na Bolívia e os elementos da sua constante transformação | Ananda Winter

YASHAR, Deborah J. Contesting Citizenship in Latin America: the rise of indigenous movements and the postliberal challenge. New York: Cambridge University Press, 2005.

ZABALA CANEDO, María Lourdes. Mujeres Cuotas y Ciudadania en Bolivia. Coordinadora de la Mujer, 1998. 